\title{
Anti inflammatory Activity of the Ethanol Extract of Cinnamon (Cinnamomum burmannii) Bark using Membrane Stabilization Method and Protein Denaturation
}

\author{
Annisa Shalihah, Fransiska M. Christianty, Fifteen A. Fajrin* \\ Department of Pharmacy, Universitas Jember, Jl. Kalimantan I/2 Jember, 68121, Indonesia
}

Submitted 01 November 2021; Revised 03 November 2021; Accepted 03 December 2021; Published 30 December 2021

*Corresponding author: fiezz.15@gmail.com

\begin{abstract}
Inflammation is the body's reaction to infection, irritation, or foreign substances, as the body's defenses. Inflammatory mediators such as bradykinin, prostaglandins, fluid extravasation, and tissue damage are essential to protect our body as an inflammatory response. One of the plants in Indonesia that can develop is Cinnamomum burmannii. These plants are identified to contain some substances such as flavonoid, tannin, and saponin. The purposed to determine the anti-inflammatory activity of the Cinnamomum burmannii extract using in vitro method compared with diclofenac sodium. Cinnamon bark was extracted using $96 \%$ ethanol, and phytochemical screening was determined. Anti-inflammatory test in vitro using two methods, membrane stabilization and protein denaturation inhibition. Antiinflammatory activity using the membrane stabilization method, the IC50 of the extract was $84.45 \pm$ $3.55 \mu \mathrm{g} / \mathrm{mL}$, while in the protein denaturation method, the IC50 of the extract was $57.412 \pm 0.718 \mu \mathrm{g} /$ $\mathrm{mL}$. Even though the IC50 of the extract was lower, it is still lower than diclofenac sodium as drug control. Our result showed that cinnamon is potential as an antiinflammation and needs to be developed further.
\end{abstract}

Keywords: Antiinflammatory; Cinnamomum burmannii; Membrane stabilization: Protein denaturation

\section{Aktivitas Anti Inflamasi Ekstrak Etanol Kulit Kayu Manis (Cinnamomum Burmannii) dengan Metode Stabilisasi Membran dan Denaturasi Protein}

\begin{abstract}
Abstrak
Inflamasi adalah reaksi tubuh terhadap infeksi, iritasi atau zat asing, sebagai upaya mekanisme pertahanan tubuh. Migrasi sel, pelepasan mediator seperti bradikinin, prostaglandin, ekstravasasi cairan, kerusakan jaringan dan perbaikannya yang ditujukan sebagai upaya pertahanan tubuh yang merupakan respon inflamasi. Salah satu sumber tanaman yang berpotensi sebagai antiinflamasi adalah kayu manis. Kulit kayu manis dikenal mengandung flavonoid, tannin, dan saponin dimana memiliki aktivitas antiinflamasi. Tujuannya untuk mengetahui adanya pengaruh ekstrak etanol kayu manis terhadap stabilisasi membran dan penghambatan denaturasi protein secara in vitro dibandingkan natrium diklofenak. Kulit kayu manis diekstraksi dengan etanol 96\% dan dilakukan skrining fitokimia. Ekstrak kemudian diuji antiinflamasi in vitro dengan dua metode yaitu stabilisasi membran dan penghambatan denaturasi protein. Ekstrak etanol kulit kayu manis mengandung senyawa tanin, flavonoid, steroid, triterpenoid dan saponin. Uji antiinflamasi metode stabilisasi membran nilai IC50 ekstrak etanol kulit kayu manis sebesar $84,45 \pm 3,55 \mu \mathrm{g} / \mathrm{mL}$, sedangkan pada penghambatan denaturasi protein didapatkan nilai IC50 57,412 $\pm 0,718 \mu \mathrm{g} / \mathrm{mL}$. Nilai IC50 ekstrak masih lebih besar dibandingkan natrium diklodenak sebagai kontrol positif. Hasil ini menunjukkan bahwa ekstrak etanol kulit kayu manis berpotensi sebagai antiinflamasi dengan nilai IC50 yang kuat berada di bawah $100 \mu \mathrm{g} / \mathrm{mL}$.
\end{abstract}

Kata Kunci: Antiinflamasi; Kayu manis; Denaturasi protein, Stabilisasi membran 


\section{Introduction}

Inflammation involves various physiological processes in the body, such as activating mediators, enzyme activation, cell activation, tissue repair, and the movement of white blood cells through capillaries to areas of inflammation. ${ }^{1}$ Inflammation is often painful and involves increased vascular permeability, protein denaturation, and membrane changes. Injured tissue cells release kinins, prostaglandins, and histamine, which collectively cause vasodilation and increased capillary permeability. ${ }^{2}$ Changes in cell membranes and protein denaturation with the occurrence of inflammatory mechanisms. The red blood cell membrane is similar to the lysosomal membrane, ${ }^{3}$ which plays a role in the inflammatory process. Stabilizing the lysosomal membrane is vital in limiting the inflammatory response. Protein denaturation is the process of protein loss of secondary and tertiary structures caused by external compounds, such as strong acids, strong bases, inorganic salts, heating, and organic solvents. ${ }^{4}$ The autoantigens produced in inflammatory disease may be due to the protein denaturation process. ${ }^{5}$

In general, to overcome inflammation, drugs from the non-steroid anti-inflammatory drugs (NSAID) group and steroid groups help reduce pain and swelling due to inflammation. ${ }^{6}$ However, in reality, long-term use of these drugs poses a risk of gastrointestinal, cardiac, and other toxicity. ${ }^{7-8}$ Therefore, research to find active compounds from plants that have the potential as new therapies that are more effective and safe is needed.

One of the plants from Indonesia that can have an anti-inflammatory effect is the Cinnamomum burmannii, also known as cinnamon. ${ }^{9}$ reported that four species of Cinnamomum, i.e., C. burmannii, C. zeylanicum, C. aromaticum, and C. loureiroi, have the same health benefits used for various conditions, including digestive disorders, inflammation, diabetes mellitus, and infections. Previous research conducted ${ }^{10}$ showed that aqueous and ethanol extracts from the red ginger rhizome and cinnamon bark inhibit cyclooxygenase (COX)-2 and xanthine oxidase (XO) enzymes in vitro.

Based on ethnopharmacological data, C. zeylanicum, known as Ceylon, provides an anti-inflammatory effect in vivo. ${ }^{11}$ Chemical screening ${ }^{12}$ shows that cinnamon bark contains flavonoid compounds, saponins, and tannins. Flavonoids and saponins have been reported to stabilize lysosomal membranes in vivo and in vitro assays. Meanwhile, tannins and saponins can bind cations, thereby stabilizing the erythrocyte membrane. ${ }^{13}$

Sufficient scientific evidence has not followed the widespread use of cinnamon bark in the community. The study of ethanol extract from cinnamon bark as an antiinflammatory in vitro using stabilization membrane and protein stabilization method has never been done before. Based on approach chemotaxonomy and research that has been done previously.

\section{Materials and methods}

\subsection{Tools}

Analytical balance (Ohaus PA214), oven (Hettich, EBA 20), centrifuge (Hettich), $\mathrm{pH}$ meter (Eutech), rotary evaporator (Heidolph), water bath (Thermostat Water Bath HH-6), and UV-Vis spectrophotometer (Hitachi U-2910).

\subsection{Materials}

96\% ethanol (Merck), distilled water (Otsuka), NaCl (Sigma), Na2HPO4 (Merck), Sodium diclofenac (Sigma), 1N HCl (Merck), bovine serum albumin (BSA, Sigma), fresh human blood (Indonesian Red Cross Society), normal saline (Widatra Bhakti). The cinnamon powder was obtained and determined by Materia Medica, Batu District, Malang, East Java (No. 074/356A/102.7/220).

\subsection{Methods}

\subsubsection{The Extraction of Cinnamon Bark}

\section{Extract}

Cinnamon bark powder was extracted using the maceration method for three days using $96 \%$ ethanol solvent with a ratio of 1:10. The filtrate obtained was then concentrated with a rotary evaporator, and the extract yield was calculated. ${ }^{12}$ 
2.3.2. Phytochemical Screening of Ethanol Extract of Cinnamon Bark

Analyzed to detect flavonoid compounds, alkaloids, saponins, triterpenoids, steroids, phenols, and tannins. ${ }^{13}$

\subsubsection{Anti-Inflammatory Activity using Membrane Stabilization Method}

Fresh human blood $(5 \mathrm{~mL})$ was centrifuged at $3000 \mathrm{rpm}$ for $10 \mathrm{~min}$. The top layer (supernatant) was separated so that what remains in the tube is the bottom layer (pellet). The pellets that had been obtained were then rinsed using $5 \mathrm{~mL}$ of normal saline. Each rinse was followed by centrifugation. The rinsing process was carried out three times. The part used was the pellet containing red blood cells from the first rinse to the last rinse. The next step was to make a $10 \% \mathrm{v} / \mathrm{v}$ suspension of red blood cells in saline phosphate buffer $\mathrm{pH} 7.4$ (0.2 g NaH2PO4, $1.15 \mathrm{~g} \mathrm{Na} 2 \mathrm{HPO} 4$, and $9 \mathrm{~g}$ $\mathrm{NaCl}$ dissolved in $1 \mathrm{~L}$ of distilled water) by pipetting $9 \mathrm{~mL}$ of saline phosphate buffer and then mixed in a tube. The reaction mixture containing $1 \mathrm{~mL}$ of the pellet was then mixed until homogeneous. ${ }^{14}$ Sodium diclofenac solution as a positive control was made with concentrations of $20,40,60,80,100$, and 120 $\mu \mathrm{g} / \mathrm{mL}$ in saline phosphate buffer. The ethanol extract of Cinnamon bark was prepared at $20,40,60,80,100$, and $120 \mu \mathrm{g} / \mathrm{mL}$ in saline phosphate buffer.

This test was carried out by reacting 5 $\mathrm{ml}$ of the test compound solution at various levels with $0.1 \mathrm{ml}$ of $10 \%$ red blood cell suspension. The solution was incubated at 56 ${ }^{\circ} \mathrm{C}$ for 30 minutes at room temperature. The solution was centrifuged at $3000 \mathrm{rpm}$ for 5 minutes, and the absorbance was measured at $540 \mathrm{~nm}$. The test was done in triplicate. ${ }^{14}$
The IC50 was determined through the linear regression equation of each test compound.

\subsubsection{Anti-Inflammatory Activity using} Protein Denaturation Method

A total of $0.5 \mathrm{ml}$ of the solution added $0.2 \%$ bovine serum albumin to $5 \mathrm{ml}$ and incubated at room temperature for 30 minutes. The solution was then boiled at $100^{\circ} \mathrm{C}$ for 45 minutes and allowed to cool at room temperature for 25 minutes. The solution was vortexed for 1 minute and measured at $660 \mathrm{~nm}$. The test was carried out in three replications. ${ }^{15}$ Sodium diclofenac solution as a positive control was made with concentrations of $20,40,60,80,100$, and 120 $\mu \mathrm{g} / \mathrm{mL}$ in $96 \%$ ethanol. The ethanol extract of cinnamon bark solution was prepared with $20,40,60,80,100$, and $120 \mu \mathrm{g} / \mathrm{mL}$ in $96 \%$ ethanol. The IC50 value was determined through the linear regression equation of each test compound.

\subsection{Data Analysis}

All IC50 data were displayed in mean \pm SD. IC50 was compared in each group using independent $\mathrm{t}$-test analysis with a $95 \%$ confidence level. Significant differences between groups were indicated by the $p$-value $<0.05$.

\section{Result}

The percentage of cinnamon bark yield obtained was $32.63 \% \mathrm{w} / \mathrm{w}$. Phytochemical screening of the ethanolic extract from Cinnamon bark found flavonoids, saponins, triterpenoids, steroids, and tannins, as shown in Table 1.

Based on the in vitro anti-inflammatory testing results using protein denaturation

Table 1. Phytochemical Screening Result from Ethanol Extract of Cinnamon Bark

\begin{tabular}{ccc}
\hline Compounds & Result & Interpretation \\
\hline Alkaloid & no brown or red-orange precipitate occurs & Negative \\
Saponin & Stable foam is formed & Positive \\
Triterpenoid & Formation of purplish-red color & Positive \\
Steroid & A red ring is formed & Positive \\
Flavonoid & Purple color & Positive \\
Tannin & Formed blackish-green color & Positive \\
Polyphenol & no blackish-green change after adding FeCl3 & Negative \\
\hline
\end{tabular}


Table 2. in vitro anti-inflammatory testing results

\begin{tabular}{|c|c|c|c|c|c|c|c|c|c|c|}
\hline \multirow[t]{2}{*}{ Group } & \multicolumn{5}{|c|}{$\begin{array}{c}\text { Membrane stabilization } \\
\% \text { inhibition in concentration (ppm) }\end{array}$} & \multicolumn{5}{|c|}{$\begin{array}{c}\text { Protein denaturation } \\
\% \text { inhibition in concentration (ppm }\end{array}$} \\
\hline & 20 & 40 & 60 & 80 & 100 & 20 & 40 & 60 & 80 & 100 \\
\hline $\begin{array}{l}\text { Diclofenac } \\
\text { Sodium }\end{array}$ & 37.5 & 43.1 & 48.4 & 53.7 & 60.2 & 51.7 & 53.0 & 56.9 & 60.6 & 66.8 \\
\hline $\begin{array}{l}\text { Ethanol extract of } \\
\text { Cinnamon bark }\end{array}$ & 18.9 & 24.0 & 35.0 & 50.6 & 59.8 & 34.3 & 43.4 & 51.2 & 58.6 & 60.3 \\
\hline
\end{tabular}

and membrane stabilization methods, the percentage of inhibition of extract in both method were lower than diclofenac sodium as seen in Table 2. The IC50 of the ethanol extract of cinnamon bark was below $100 \mu \mathrm{g} /$ $\mathrm{mL}$ (Figure 1).

\section{Discussion}

The yielded result obtained in this study was slightly different from other research, which obtained $29.25 \%{ }^{12}$ and $29.59 \%{ }^{16}$ The difference in yields obtained may be due to the extraction method used and the difference in the place of plant sampling.

The principle of measuring antiinflammatory activity in membrane stabilization testing is a decrease in absorbance in the test solution mixture. The smaller the absorbance value produced, the smaller the hemolysis that occurs, so the more significant the anti-inflammatory activity possessed by the sample. ${ }^{14}$ The IC50 value is an inhibitor concentration that can inhibit hemolysis activity by $50 \%$. The smaller the IC50 value, the greater the inhibitory ability. The membrane stabilization activity test showed that cinnamon extract had an IC50 of $84.45 \mu \mathrm{g} / \mathrm{mL} \pm 3.55$. This IC50 value is higher

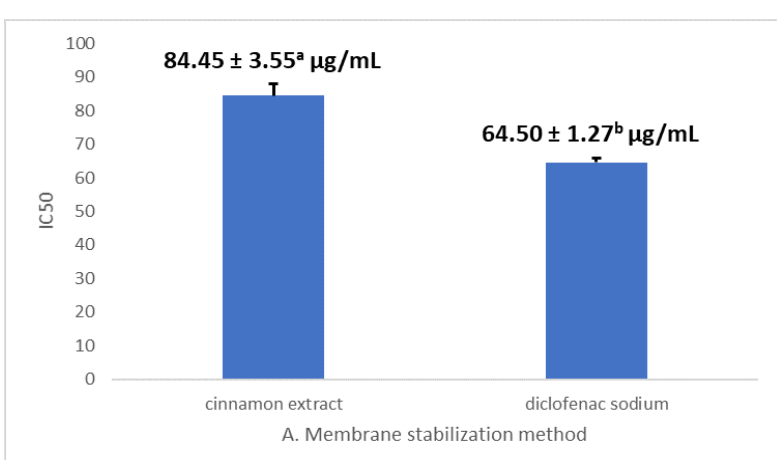

than the IC50 value of diclofenac sodium, which is $64.505 \mu \mathrm{g} / \mathrm{mL} \pm 1.272$. Based on the results, diclofenac sodium has a stronger hemolytic activity than cinnamon extract.

Another test of anti-inflammatory activity is used protein denaturation method. The denaturation process in this study is stimulated by heat.4 When the temperature rises, it can increase the kinetic energy and cause the molecules that make up the protein to move or vibrate very quickly, damaging the molecule. The protein denaturation process takes place permanently and does not change. A denatured protein will decrease its liquid solubility to settle. ${ }^{17}$ Proteins in the body are susceptible to denaturation caused by the formation of free radicals that cause an inflammatory mechanism by stimulating the release of inflammatory mediators. ${ }^{18}$ The principle of inhibition of protein denaturation can be seen from the interaction of the sample solution with Bovine Serum Albumin. Samples that inhibit protein denaturation $>20 \%$ are considered anti-inflammatory activity and can be used as reference values for drug development. ${ }^{18}$

The cinnamon extract has protein denaturation inhibitory activity, which can

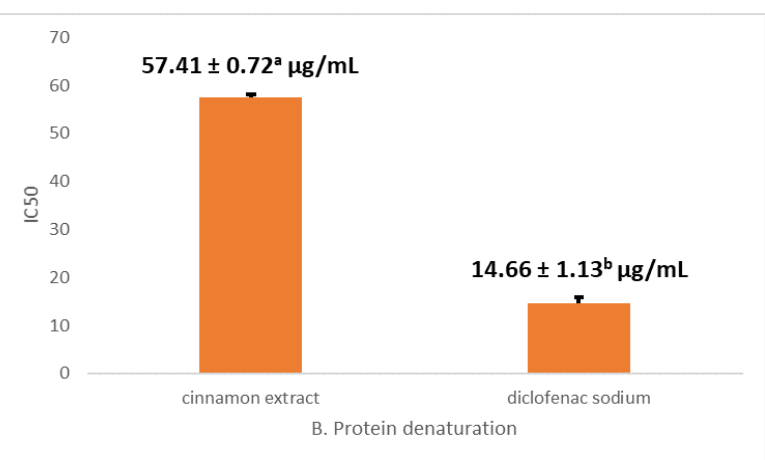

Figure 1. IC50 Result using Membrane Stabilization (A) and Protein Denaturation (B) Test. The analysis was performed using an independent t-test at a 95\% confidence level. Different superscript letters showed significant differences $(\mathrm{p}<0.05)$ 
be seen from the IC50 value of $57.412 \mu \mathrm{g} /$ $\mathrm{mL} \pm 0.718$. This value is still higher than the IC50 of diclofenac sodium, which is $14.655 \mu \mathrm{g} / \mathrm{mL} \pm 1.131$. The IC50 value is interpreted as the sample concentration in inhibiting protein denaturing activity by $50 \%$. The smaller the IC50 value, the higher the potential of the extract in inhibiting protein denaturation IC50 of sodium diclofenac in inhibiting protein denaturation is classified as very strong with IC50 value $<50$, however, the cinnamon extract was classified as strong because the IC50 was between 50$100 \mu \mathrm{g} / \mathrm{mL} .{ }^{15}$ Diclofenac sodium showed a more potent protein denaturing activity than cinnamon extract. Diclofenac sodium is a non-steroidal anti-inflammatory agent that can prevent inflammatory mediators' release. ${ }^{19}$

The ethanolic extract of cinnamon bark contained some constituents such as flavonoids, saponins, triterpenoids, steroids, and tannins. Flavonoids are known to have anti-inflammatory activity with the mechanism of action of inhibiting the formation of prostaglandins through the cyclooxygenase (COX) and lipoxygenase-5 (LOX-5) pathways. ${ }^{20}$ Flavonoid and saponins compounds also have anti-inflammatory activity because they inhibit inflammatory mediators and free radicals, ${ }^{21}$ while tannin and saponin compounds stabilize membranes by binding to cations. ${ }^{22}$ Free radical inhibitors could stabilize erythrocyte membranes from hypotonic solutions. ${ }^{23}$ Compounds that are also thought to have the ability to stabilize membranes are triterpenoids. The same thing was also reported ${ }^{24}$ that flavonoid and triterpenoid compounds from Centella Asiatica extract were responsible for antiinflammatory activity in stabilizing red blood cell membranes

In another species of cinnamon, such as C. zeylanicum and C. cassia were found E-cinnamaldehyde and o-methoxycinnamaldehyde. This compound was potent as antiinflammation after being tested in RAW.267 and J7774A.1. ${ }^{25}$ Our result about the activity of the cinnamon extract in the in-vitro study has completed other results previously. The latest study revealed that cinnamon bark oil showed anti-inflammatory activity in the in-vivo study using male Wistar rats. ${ }^{26}$ The relationship between the in vitro and in vivo study explained that if the cinnamon could reach the effective concentration in systemic, cinnamon and its component might be necessary for inflammation disease.

\section{Conclussion}

Based on the research, the cinnamon extract has potent anti-inflammatory activity, even it is still lower than diclofenac sodium. The exact mechanism needs to explore how the cinnamon extract can inhibit protein denaturation and stabilize the membrane.

\section{References}

1. Chen L, Deng H, Cui H, Fang J, Zhuo $Z$, Deng J, et al. Inflammatory responses and inflammation-associated diseases in organs. Oncotarget. 2018; 9(6): 7204 7218.

2. Sugimoto MA, Sousa LP, Pinho V, Perretti M, Teixera MM. Resolution of inflammation: what controls its onset? Frontiers in Immunology. 2016;7:160.

3. Ammendolia DA, Bement WM, Brumell $\mathrm{JH}$, Plasma membrane integrity: implications for health and disease. BMC Biol. 2021;19:71.

4. Zink J, Wyrobnik T, Prinz T, Schmid M. Physical, Chemical and Biochemical Modifications of Protein-Based Films and Coatings: An Extensive Review. Int. J. Mol. Sci. 2016;17:1376

5. Chaterjee $P$, Chandra S, Dey P, Bhattacharya S. Evaluation of antiinflammatory effects of green tea and black tea: A comparative in vitro study. $\mathrm{J}$ Adv Pharm Technol Res. 2012;3(2): 136 -138 .

6. Bacchi S, Palumbo P, Sponta A, Coppolino MF. Clinical Pharmacology of Non-Steroidal Anti-Inflammatory Drugs: A Review, Anti-Inflammatory \& AntiAllergy Agents in Medicinal Chemistry. 2012;11(1).

7. Williams DM, Respiratory Care. 2018;63(6):655 - 670 .

8. Wongrakpanich S, Wongrakpanich A. A Comprehensive Review of NonSteroidal AntiInflammatory Drug Use in 
The Elderly. Aging and Disease. 2018; 9(1):143 - 150 .

9. Chen, P., J. Sun, dan P. Ford. Differentiation of the four major species of cinnamons (C.burmannii, C. verum, C. cassia, and C. loureiroi) using a flow injection mass spectrometric (fims) fingerprinting method. Journal of Agricultural and Food Chemistry. 2014;62(12):2516-2521.

10. Yustinus CS. Daya inhibisi ekstrak rimpang jahe merah dan kulit kayu manis terhadap aktivitas enzim siklooksigenase 2 dan enzim xantin oksidase secara in vitro (skripsi). Bogor: 2010;. Theses (disertasi). Bandung: Universitas Padjadjaran; 2010

11. Damput FS. Uji Efek Antiinflamasi Ekstrak Etanol 70\% Kulit Batang Kayu Manis (Cinnamomum zeylanicum breyn) pada Tikus Putih (skripsi). Jakarta: Universitas Indonesia; 2013.

12. Anggriawan MB, Roswiem AP, Nurcholis DW. Potensi ekstrak air dan etanol kulit batang kayu manis padang (Cinnamomum burmannii) terhadap aktivitas enzim a-glukosidase. Journal Kedokteran Yarsi. 2015;23(2):91-102.

13. Wang T-y, Li Q, Bi K-s. Bioactive flavonoids in medicinal plants: Structure, activity and biological fate. Asian Journal of Pharmaceutical Sciences. 2018;13(1):12 - 23.

14. Chanda S, Archana JR. In vitro antiinflammatory activity of syringic acid. International Journal of Pharmacy and Pharmaceutical Science. 2019;11(2):71 73.

15. Rahmawati, Widiastuti H, Sulistya E. In Vitro Anti-Inflammatory Assay of Bitter Melon (Momordica charantia L.) Ethanol Extract. Jurnal Fitofarmaka Indonesia. 2020;7(3):1 - 4

16. Herdwiani W, Rejeki ES. Uji Aktivitas Sitotoksik Ekstrak Kulit Batang Kayu Manis (Cinnamomum burmannii) Terhadap Kultur Sel T47D. Jurnal Farmasi Indonesi., 2015;12(2):102 - 113.

17. Roche J, Royer CA. Lessons from pressure denaturation of proteins. J. R. Soc. Interface. 2018;15:20180244.

18. Adarsh VM, Ajay KP, Kavitha D, Anurag KB. Anti Denaturation And Antioxidant
Activities Of Annona Cherimola In-Vitro. Int J Pharm Bio Sci. 2011;2(2):1 - 6 .

19. Crofford LJ. Use of NSAIDs in treating patients with arthritis. Arthritis Res Ther. 2015;15:S2.

20. Panche AN, Diwan AD, Chandra SR. Flavonoids: an overview. J Nutr Sci. 2016;5:e47.

21. Attiq A, Jalil J, Husain K, Ahmad W. Raging the War Against Inflammation With Natural Products. Front. Pharmacol. 2018;9:976

22. Oyedapo OO, Akinpelu BA, Akinwunmi KF, Adeyinka MO, Sipeolu FO. Red blood cell membran stabilizing potentials of extracts of Lantana camara and its fractions. International Journal of Plant Physiology and Biochemistry. 2010;2(4):46 - 51.

23. Olchowik E, Lotkowski K, Mavlyanov S, Abdullajanova N, Ionov M, Bryszewska $M$, et al. Stabilization of erythrocytes against oxidative and hypotonic stress by tannins isolated from sumac leaves (Rhus typhina L.) and grape seeds (Vitis vinifera L.). Cell Mol Biol Lett. 2012;17(3):333 -48 .

24. Chippada SC, Volluri SS, Bammidi SR, Vangalapati $M$. In vitro anti inflammatory activity of methanolic extract of Centella asiatica by HRBC membran stabilisation. Journal of Chemistry. 2011;4(2):457 460 .

25. Gunawardena D, Karunaweera N, Lee S, van Der Kooy F, Harman DG, Raju R, et al. Anti-inflammatory activity of cinnamon (C. zeylanicum and C. cassia) extracts identification of E-cinnamaldehyde and o-methoxy cinnamaldehyde as the most potent bioactive compounds. Food Funct. 2015;;6(3):910 - 919 .

26. Budiastuti, Nurcholida RD, Primaharinastiti R, Sukardiman. AntiInflammatory Activity of Cinnamon Bark Oil (Cinnamomum burmannii (Nees \& T. Nees) Blume from Lombok Timur Indonesia. Pharmacogn J. 2021; 13(4):1005 - 1013. 